Peer review: This article has been subject to a double blind peer review process

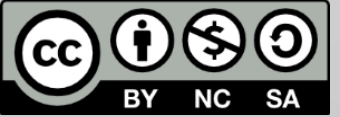

(c) Copyright: The Authors. This article is issued under the terms of the Creative Commons Attribution NonCommercial Share Alike License, which permits use and redistribution of the work provided that the original author and source are credited, the work is not used for commercial purposes and that any derivative works are made available under the same license terms.

\section{A Conversation with...Alex Callinicos}

\author{
Ali Saqer* \\ Department of Politics and International Studies, University of Warwick \\ *Correspondence: A.Saqer@warwick.ac.uk
}

\begin{abstract}
Professor Alex Callinicos is a renowned social theorist and scholar of international political economy. He conducts research on Marx and Marxism, European social and political theory, contemporary political philosophy, critical theory, historiography, and international political economy. His work provides invaluable insights on issues of race and racism, social justice, the Third Way, imperialism, austerity, and EU politics, among many other fascinating contemporary issues. Alex studied Philosophy, Politics, and Economics at Balliol College, Oxford, and Philosophy of Science at the London School of Economics before writing a DPhil on Marx's Capital, also at Balliol. He was a Junior Research Fellow in Contemporary Social Thought at St Peter's College, Oxford from 1979 to 1981, after which he taught social and political theory at the Department of Politics at the University of York until 2005, when he moved to King's College London. Alex is currently the Professor of European Studies at King's and editor of International Socialism. Alex has been an active contributor to the development of the movement for another globalization, participating in the World Social Forum and an animator of the European Social Forum. Among his best known books are The Revolutionary ldeas of Karl Marx (1983), Against Postmodernism (1990), Social Theory (1999), An Anti-Capitalist Manifesto (2003), The Resources of Critique (2006), Imperialism and Global Political Economy (2009). His most recent book is entitled Deciphering Capital: Marx's Capital and its Destiny (2014).
\end{abstract}

Keywords: Eurozone crisis, Greece, critical theory, euro, European Union

\section{The Eurozone Crisis and the Challenge for Future Europe}

A quick browse through the European Union's official website tells you a very short, but strong, story about the Euro: 'the Euro is the most tangible proof of European integration'. This makes you think: well, it must be because otherwise it would be rather difficult to make sense of why in the midst of a crippling economic crisis the Greek government 
bowed before Europe's powerful elite in August 2015. Let us remember though, that this happened despite popular opposition to the deal struck with the EU institutions in August 2015. A third bailout package was made conditional on putting austerity policies in place in Greece. Bearing in mind the nature of the demanded reforms which were imposed on Tsipras's government, this stands in stark contrast with the Eurozone's own promise to its member countries. The EU website states that 'the benefits of the common currency are immediately obvious to anyone travelling abroad or shopping online on websites based in another EU country'. However, it is hard to imagine how austerity policies will allow the Greeks to do much travelling and shopping online. Their determination for Eurozone membership ought to have another explanation.

2015 represented the peak year of the Greek financial crisis, since then we have heard very little about Greece and its crisis. Today, the Eurozone crisis has become only one of many manifestations of the challenges facing European integration. Now, the EU is faced with two other challenges: the refugee crisis, which put Europe's Schengen agreement under extreme pressure leading to a temporary suspension in some countries, and 'Brexit', which will be voted on in the UK on 23 June 2016. To most Europeans these are structural and existential challenges, at least to a Europe as people have known, and imagined, it to be. However, the absence of the Greek crisis from mainstream media news should by no means be perceived as if everything is alright now and that Greece has recovered from her misfortunes. Neither does it mean that the country will stand up back on her feet anytime soon, at least in a way that would conform to the positive imagination Greeks had upon joining the Eurozone in 2001. Greece's drama threatened a potential collapse of the Eurozone and ushered a weakening of the coherence of the EU.

Alex Callinicos has written extensively on the on-going social and political transformations of Europe. His writings are extremely helpful to our understanding of the current crisis in Europe. Even before the birth of the Euro, Alex wrote in 1997 of the 'mounting crisis' of Europe, specifically on how, from its very inception, a well-functioning Eurozone was made conditional upon members' adoption of austerity policies. He links this to the fact that EU decision-making institutions reflect 'the values, priorities, and prejudices of a capitalist predominantly free market economic system' (Callinicos, 1997). On many occasions, as in The Crisis of Our Time (2011), The Internationalist Case against the European Union (2015), and most importantly in Contradictions of Austerity (2012) and Bonfire of Illusions (2010), Alex unpacked the political and economic challenges of 
the European Monetary Union throughout its development to date. He wrote on the accompanying class polarisation occurring alongside the development of the EMU and discussed the various positions on EU membership in the UK and elsewhere. In all of these accounts, including his latest work on Deciphering Capital: Marx's Capital and its Destiny (2014), Alex draws strong correlations between the crisis of the EU and that of capitalism more generally. He highlights in the most interesting fashion the limits to neoliberalism which is, in most contemporary analyses of the economic and political crisis of our time, advocated as the solution rather than the disease.

These, and other, works have inspired me to conduct an interview with Alex and discuss one of the main areas where EU democracy and its institutions have failed, the Eurozone crisis. Indeed, such a discussion could give us a hint on where the EU is going today with a potential Brexit and an on-going refugee crisis. Therefore, with the aim of escaping the mainstream convictions of the Eurozone crisis and presenting an alternative account of the crisis, I met with Professor Callinicos at King's College London in August 2015. I asked him about how and why the crisis has unfolded, what the political and economic implications are of the way it was handled for the EU post-crisis, and about the human impact of the crisis as well as the social and economic transformations underway in Europe.

\section{The Interview}

Ali Saqer (AS): Most people seem to be convinced that the current crisis in the Eurozone is solely a financial crisis. There is, however, another side to the story from the point of view of critical economists. They believe it is not actually a financial crisis per se, it is deeper than that. Can we think of an alternative account of the Eurozone crisis, and the Greek crisis in particular, than the one dominant in mainstream media and studies? How would you describe the current crisis in Europe?

Alex Callinicos (AC): The most general way I would describe it is that the Eurozone crisis, let's remember it has been going around now for more than five years, is the specific form taken by the global economic crisis that developed in 2007-8. We can see what the Marxist blogger Michael Roberts calls the long depression manifested most sharply in the Eurozone. This goes against the EU common sense, which is basically that the Eurozone is really good but it had bad luck to be hit, on the one hand by a financial crisis manufactured at Wall Street and, on the other hand, by the laziness and greed of southern Europeans - that is a fantasy. 
AS: Ok, in that regard there are actually few people, such as Stathis Kouvelakis, a reader in political theory at King's College, who describes the crisis in the following way:

Before the 2008-2010 crisis, the most Europhile countries within the European Union were precisely those of the south and the periphery. It must be understood that for these countries, EU membership signifies a certain modernity, both economic and political, an image of prosperity and power that the Euro comes to validate at a symbolic level. This is the fetishistic aspect of money that Karl Marx emphasised: having the common currency in their pockets, the Greeks symbolically reach the same level as the Germans or the French. (2015)

So the implication of this is that: there was at the very beginning of the Eurozone a divide between economically weak and strong countries, and the south was seen to be a buffer zone for the strong countries, in order to communicate certain financial difficulties or ambitions that the stronger might have in their neighbourhood. The Germans, for example: there are a lot of stories about how the German governments exploit the south. There seems to be this divide and the Greeks bought into this idea that the Eurozone will bring them closer together with the strongest.

AC: Yes, I am sure that helps to explain why opinion polls in Greece show that the majority wants to stay in the Euro but already Greece's participation in the Euro isn't the same as that of other Eurozone member states because of the capital controls that mean that Greeks are still restricted in how much money they can take out of their bank accounts and how much money they can either can take out or bring in to Greece. A Euro in Greece isn't the same as a Euro in Germany or France or whatever. This did not start with Greece, it started with the crisis in Cyprus back in 2013 and the kind of capital controls that were imposed them. So already we have first and second class Euros: it is not a fungible currency or equally fungible across the entire the Eurozone. The Euro is already a very strange currency.

AS: Would that mean it is actually not functioning as a common currency? I mean it is a common currency in theory and since it, in reality, means different things or represents different ambitions for different people...

AC: Yes, you have different ideological investments in the Euro. And for Greece I think Stathis is right: being in the Euro is being part of a sort of west European modernity. But there was a lot of suspicion of the Euro when it was launched in Germany. But I am not talking about those kinds of ideological investments. I am just saying to be a resident of Greece and 
hold Euros is different from being a resident of Germany and hold Euros or even to the others being residents of Britain because I have freer access to Euros as a UK citizen even Greeks do. So already we can see deterioration in the quality of the common currency simply as form of money.

AS: This actually makes sense, if we take the Euro to be a symbolic material of this relationship between European countries, if it has this kind of different meaning for different countries in terms of access, value, freedom, in terms of strong or weak relationship with the Euro, what does this tell us about Europe in general?

AC: Well, it shows that Europe isn't in any sense a harmonious community. I mean that is obvious now. Europe is shaped by very sharply divergent and antagonistic national and class interest. I mean, I should say the attitudes I talked about both involve large elements of illusion that the Euro has not been good for Greece. It has been very good not for all Germans but very good for German capitalists and this is maybe something we should discuss.

AS: Would you like to expand a bit more on this point?

AC: Well, I think if we want to look at what the Eurozone crisis is about, there are three dimensions. One being the crisis is about accumulation and profitability that affects the advanced capitalist world, generally, including the Eurozone countries. Let's just get back at that. Secondly, there are the design flaws in the Euro, and, in particular, something that was identified very early: that the Euro was a common currency supported by, on the one hand, a central bank, which, as we have discovered, is not a lender of last resort. So it does not perform the most basic functions of a central bank. That, on the other hand, does not meet the kind of conditions for successful monetary union. A monetary union means that countries give up the ability to devalue their own currencies and thereby get out of economic trouble that way. To stop the kind of devastation we have seen in Greece, you need alternative mechanisms; for example, the kind of fiscal mechanisms that German politicians call with horror a transfer union and that are entirely standard in places like the United States. A region that gets into trouble pays less in taxes and gets more in terms of welfare benefits. So there is a redistribution in favour of a transfer in other to badly affected Greece and regions. Those mechanisms don't exist in the Euro zone and the way in which it has been reconstructed since 2010 have created more obstacles to those redistributive mechanisms.

The third is what we have seen in the re-organisation of production and trade in the Euro zone in which in particular German capitalism has 
rebuilt itself since the crisis at the time of the Unification in the early 1990 s by squeezing German wages, shifting production to eastern and central Europe, where there is lots of cheap but skilled workers and on the basis of that reorganization, increasingly directing its exports outside not just the Euro zone and Europe, towards most importantly China. And what that has really led to is, I think, is a breakdown in the kind of virtuous circle that was the economic basis of European integration from the 1940s onwards, where Germany was the big export engine that created a big market for the manufactured goods of the other members, firstly EEC and then the European Union. For southern European countries this setup has broken down, so they find it harder to get markets in northern Europe. The areas where they produce are ones where they are under increasing competition from the Global South but, at the same time, they are heavily on Germany, in particular, for their complex manufacturing exports. So they need German imports, but they find it hard to access the German market to get the money to pay for those exports.

Now, initially the Euro launch pasted over these cracks because what you had is an integration of financial markets across Europe which led to convergence of interest rates at German levels. It is, more broadly, because of the credit bubble in the mid-2000s interest rates fell sharply so Greece could get by borrowing heavily and it was what you seen in particular in the 2000s. In Spain, there was a build-up of private sector borrowing contrary to all the north European myths about how the crisis is just to do with the Greek government borrowing to pay higher pensions that Germany and that kind of thing. And then we have the financial crash, which was a financial crash for the European banks as much as for the American or the British banks. German banks were particularly stupid in buying the kind of trash in the shape of derivatives that American banks were constructing in the second half of the 2000s. The crash comes and there has been a socialisation of private debt that pushes countries like Spain and Greece deep into the red or in the case of Greece even deeper into the red. It is in this context in which we get in these whole rescues which of course were bailouts, they notoriously have mainly paid back the banks and rescued the banks who lent the money in the first place.

AS: In this sense we can actually speak of two-level financial management failure: one is global (advanced countries), and another that is European...

AC: I'd see the difference as more sectorial than global-regional. The German banks got burnt through their naively purchasing of collateral debt obligations and so on that were generated by the American housing 
bubble. It also led not just German banks, but French banks, in particular, and, in the case of Ireland, British banks to lend pretty imprudently at the height of the bubble. So when we talk about the financial bubble I think it is best to see it as a unitary phenomenon that takes different forms in different countries...say you got a housing bubble in the US, you got a housing bubble also in Spain and Ireland and Britain, so those in and out of the Eurozone, and in Greece you have a bubble that is more focused on the stock market...they are all different manifestations of the same financial mechanisms, which I think are best seen as a displacement of the underlying crisis of over accumulation and profitability. In other words, you can't get the rate of profit back to the levels that would sustain relatively stable accumulation, so you use the financial market as a form of what Bob Brenner and Riccardo Bellofiore call 'privatised Keynesianism'. In other words, as housing prices rise people feel richer, their credit rating rises so that they can borrow and spend and that helps to keep the whole economy of the US and Europe going. Then we have a kind of divergence in which German capitalism was only peripherally involved in the kind of bubble crisis. It was not central to how German capitalism rebuilt itself; it rebuilt itself through the process I described earlier. German capitalism fights to protect itself from the negative effects of this bust and partly that involves the bailouts because they rescued the German banks but that in part involves the refusal to give debt relief to Greece, the insistence that indebted countries like Greece should pursue neoliberal reforms, and so on. The underlying rationale is that nothing must be allowed to erode the competitiveness of German capitalism so painfully rebuilt in the 2000s.

$A S:$ So, to some extent this is equal to saying that the Eurozone crisis is a product of the German politics of competitiveness; part of it was related to protecting itself from a global financial crisis that started in the US and by protecting itself, as you said, it is protecting its banks through bailouts to Greece...

AC: No, the German banks are not losing directly because what the bailouts have done has been to transfer most of the debt that was held by Greece's private creditors like the German and French banks to, in one way or another, the European central bank, the European Stability Fund (this new actor in the mess that is the Eurozone) and the IMF. This is one reason why Schäuble, the German Finance Minister, has been willing to contemplate Greece leaving the Eurozone because he reckons that the European financial system has now been protected from the implications of Grexit. So, it is the continuing effort to defend the German banks that I think is going on. More than that, German capitalism rebuilt itself on a basis that has the kind of virtuous circle of German exports helping to create a market, the expansion caused by German exports, for the rest of 
the EU. Germany is fighting to defend that model which they see to be very successful. Germany is the World's second biggest exporter. They think that is a big success, they don't want to do anything to diminish it and they think that making concessions about Greece would have a major effect on the rest of the Eurozone.

There is a very interesting interview with a German finance ministry official back in February (2015) in The Financial Times where he said, if we carry on with this debt relief plan with Greece, there will be celebrations in the Elysee and probably also in Italy. There is now this notorious interview that Yanis Varoufakis gave essentially to people in the financial market just after he resigned as finance minister, where he said that Schäuble told him that he wants Greece out of the Eurozone because he thinks that then Greece can have debt relief and so on, once it has been taken out of the box of the Eurozone and because he thinks that this would create a favourable environment in which they could impose a much tougher regime of fiscal surveillance particularly on France and Italy. If that is correct, Greece then, is a kind of casualty in a much bigger fight in which Germany (Germany here should be understood as the managers of the German state and their allies in capital) is seeking to impose a much tougher neoliberal disciplinary regime on the whole of the Eurozone to maintain the competitiveness of German capitalism).

$A S$ : whether the new rescue plan is going be consisted of more strict austerity measures on Greece, or alternatively Greece will be existing the Eurozone; in both cases, the German architects would achieve one objective which is actually enforcing this kind of stricter fiscal doctrine within the Eurozone.

AC: Yes, I mean again this is another reason to be careful about just saying Germany. It is clear that there are disagreements between Merkel and Schäuble. Merkel does not necessarily want Grexit because, you know, she does not want it to be part of her legacy to cause a country to leave the Eurozone. Perhaps what we are saying here is that already by contemplating Grexit and essentially saying to Tsipras that he has to sign up to this terrible list of measures or Greece is out. The leaders of the European Union have undermined the Maastricht treaty because the Maastricht treaty which set up the Euro was about establishing an irrevocable monetary union, now they say it is not irrevocable.

So a number of people say: is there really a difference between economic monetary union and what existed before it, the European monetary system, where the exchange rates were fixed against each other, not as tightly as they are now, they were not frozen but they had a band of variation and effectively what happened was that when German raised 
its interests rates, everyone else had to raise theirs. So, discipline was imposed on participants in the European monetary system by initiatives taken crucially by the Bundesbank in Frankfort. The question is: is EMU really any different from that? Once you say someone can leave (of course, Britain left the European monetary system back in 1992) what's the difference between the two arrangements? Economic monetary union was supposed to create an irrevocable in which it was not just the Germans who ran the show, but now we discover countries can leave and it is still the Germans running the show. So, without really probably understanding what they are doing, they opened up a big hole in the whole ideology of ever closer union which is supposed to legitimise the EU.

AS: If we see a Grexit, we might actually in the future see a Portuguese exit or a Spanish exit, unless they comply strictly with whatever rules are going to be set up for them to follow, given that Greece has been made a casualty of the system itself?

AC: Yes, but they may start thinking: well, is it worth it? Because what we have seen in Cyprus, thrown to the wolves, which was a much brief episode involving a smaller economy. There was not much of a fuss, whereas Greece has gone on for so long, partly because it is more important than Cyprus, but also because of the level of social resistance and the rise of SYRIZA, and so on. But so, we have seen two of the smaller fry thrown to the wolves. You know to a certain point politicians in other countries may start saying: is it worth it? Should we not call their bluff? Tsipras lost his nerve: he was clearly absolutely committed to staying in the Eurozone, but the fact that he has made this choice does not mean that the other politicians will. So, Greece is being crucified to terrify everyone else to comply, but it could have the opposite effect.

AS: ... which would be countries starting to consider exiting, in case they face financial difficulties to the extent that Greece has faced so far?

AC: The third biggest economy in the Eurozone is Italy. Italy has stagnated ever since the Euro was launched. The Euro has been a disaster....no doubt there are other causes, but the Euro has been an economic disaster for Italy. It is not beyond the bounds of possibility that Italy might tell Berlin and Brussels to go to hell. Beppe Grillo, the leader of the Five Star Movement, says Tsipras is a fool for accepting these terms. So everyone has watched this drama, but it does not mean they will draw a conclusion that there is no alternative to accepting what Berlin, Frankfort and Brussels demands. Now, it is true that lots of political forces involved are not very nice: you know they include the populist and fascist right. In the Greek parliament the fascist Golden 
Dawn voted against the deal. But nevertheless, if the EU elite thought through doing what they did to Greece that they were kind of closing all options, I think they were very badly mistaken.

AS: Frank Hoffer is senior research officer at the Bureau for Workers' Activities of the ILO. He said that by accepting the third rescue package, which is a humiliation deal and the accompanying forms, Tsipras has saved Germany from becoming a destroyer of EU integration. To some extent this might be the case so far. By accepting this deal Tsipras sent a signal to others: if you want to be part of a stronger deeper EU integration you would have also to accept these terms, so it could actually go either way.

AC: What does this deeper EU integration mean? It does not mean a federal state, I mean there is only one democratic way of achieving deeper integration, which is to move to a federal state, but that is not going to happen. There is no support for that.

AS: you mean social and political support for that?

AC: I am not saying that there are not politicians who are federalists: of course there are, but the German élite, on the whole, seem less in favour of federalism than they were in the past. Merkel has been criticised by many in Germany for being less enthusiastic about European integration than say Kohl was. We have the growth of nationalism, different forms of anti-EU nationalism, everywhere in Europe. So I do not think there is a political basis for creating a federal state. So, what does deeper integration mean? It means things like the fiscal pact that was agreed in 2012 which is a formula for a permanent austerity policed by the Commission and, ridiculously, the Court of Justice. So, what we have is a stronger and stronger disciplinary mechanism: that's the form that integration is taking. We thought the Troika was just a kind of emergency arrangement, (now it's a quartet, it's expanded, which, in itself, is a sign of the way this thing is becoming embedded). It is not an emergency arrangement. What we are creating is a regime of neoliberal bureaucratic surveillance throughout Europe. That is what deeper integration means and sure that is what Tsipras has signed up for, that is what he sacrificed Greece for.

AS: For ordinary people, that is a bad deal...

AC: I think it is a terrible deal.

AS: Throughout Europe, if we are consider the rise of nationalism and fascist parties and even the left parties, that are far from fascism but still want to get a better deal, like in the UK for example.... everyone seems to want a better deal from EU institutions and from the Troika. 
AC: What I describe is the future. If we look at Germany itself, as I said, one of the presuppositions of rebuilding German competitiveness was wage repression and, of course, it has grown in Germany. This set up is not a good deal for ordinary Germans. It is now a big issue in German political debate. You know, greater inequality: what do we do about it? All that kind of thing. And for the weaker economies, their ability to get access to the German market is declining now they are competing with China and Vietnam, and so on. That is the prospect they are facing.

$A S:$ The competitiveness of Germany, if this is actually one way of maintaining their competitiveness, it is kind of anti-social politics...

AC: If you read Hayek he is very clear: capitalism is all about competition and do not kid yourself, it has got nothing to do with social justice (Hayek, 1979, 1960).

AS: For leftist parties like SYRIZA and others in Spain and other European countries, this actually means a disaster, I mean since they are all buying into the same neoliberal discourse of maintaining competitiveness. The whole idea now about the rescue package with all the terms and conditions associated with it is that it is meant to restore the Greek competitiveness.

AC: To be fair to Tsipras, he says he does not believe in the detailed terms. In other words, he does not believe that the so-called reforms will restore Greek competitiveness. He is doing it because he thinks there is not a better alternative. You have already Stathis Kouvelakis: he describes Tsipras's attitude as an expression of what calls 'left Europeanism', which we also find with Podemos in Spain. In other words, traditional left politics does not have a mass audience: all we can do is to try and fight against austerity and also to seek to restore national sovereignty. This is one of the things that Pablo Iglesias, the leader of Podemos, has stressed - to fight against austerity and for national sovereignty within the framework of the European Union. Now, I think what Tsipras has demonstrated is that this 'left Europeanism' is not feasible. The EU, as it is currently constructed, is moving in the opposite direction. It is moving towards making austerity permanent and it is moving to eroding national sovereignty.

AS: What is in it for Greece? If they have actually voted $62 \%$ against austerity, most people wanted out of this and politicians thought there is a better deal and better future for the Greeks inside rather than being outside the Eurozone. That explains to some extent what is happening. If people are democratically voting against something and their leaders are not taking that into consideration, they assume the electorate do not know what is better for the future of Greece. What does that say about 
democracy? And how do Europeans like those in Greece then go about politics and their lives?

AC: From a democratic point of view it is a disaster. It is astonishing. Within a week Tsipras got this huge referendum victory rejecting austerity and then signed up to a worse deal than he originally rejected to call the referendum. It is a disaster. It does not seem to have affected his popularity yet, but in the long term it does and the danger is that it is not just his popularity that will decline but it will lead to a greater cynicism about democracy full stop, which will favour forces like Golden Dawn. You can see this very clearly in this country (UK). There has been a collapse of credibility in the conventional political élite that has benefited outside parties, not so bad in the case of the Scottish National Party, not so good in the case of UKIP. In the case of Greece, the process has got even further. SYRIZA did not win an election crucially because of the collapse of social democratic party, PASOK, so we now we are going to see the exposure of one of the more successful outsiders.

AS: That is a likelihood. To me there seems to be two forces competing... if you want to consider Greece as one single country of the Eurozone, there is a force that wants to opt out of the Eurozone and have more autonomy and get back some of the sovereignty that has been taken away by the EU Commission or the European Central Bank or the Troika. Secondly, there are SYRIZA's supporters, who actually want more justice of their membership in the Eurozone but they want it done within the Eurozone rather than outside it. Maybe this explains to some extent why Tsipras has retained some of his popularity among his supporters.

AC: Yes, I think there is a learning process that takes place in which people say increasingly we cannot have a decent existence within the Eurozone, so we better look at ways of getting out of the Eurozone, not just as a kind of nationalists leaping to the dark but as part of a search of a better alternative and economic promises. I think that is a possibility in Greece. I do not think SYRIZA does not exhaust the Greek left. There is, for example, ANTARSYA the front of the anti-capitalist left, which campaigned very vigorously during the referendum. SYRIZA, we all know, split. There is a quite significant a left-wing rebellion against the agreement within SYRIZA, and so on. So it is possible that you will the evolution of the left in a way that does offer a plausible alternative outside the Eurozone.

$A S$ : So this learning process that will teach us more about what is good for Greece?

AC: Yes, but not just Greece.... more generally. The Eurozone is good for German bosses, but not so good for German workers. 
AS: And that is because of the whole role Germany plays in the Eurozone?

AC: Yes.

AS: In this sense, can we speak of a competitiveness of the Eurozone?

AC: No, I do not think we can. This is part of the official narrative that once you had a single currency and much greater mobility of capital within the Eurozone you would have an evening up. You would have the narrowing of divergence. But the divergence has grown. I think from a Marxist perspective that is not surprising, if you reject the neoclassical idea of competition, where we all compete and we all end up rich. We understand that capitalism means an uneven and combined development and the unevenness does not disappear: it is always there, you can shift the distribution of unevenness but the unevenness is constitutive.

AS: So what could be an alternative to the whole story?

AC: Well, most obviously a socialist planned economy but I think the question is how to get from here to there? I think the radical left in Greece both inside and outside SYRIZA had put forward good policies that involve things like taking over the banks and coming up with an alternative currency. This is one of the things we discovered Varoufakis was trying do, but Tsipras would not let him take those plans beyond a certain point. For example putting in place capitals control not as a negative measure but as a means of directing investment that could reconstruct the economy in a productive way, and so on. If we look at the kind of either ANTARSYA's program or the kind of stuff that Costas Lapavitsas, the Marxist economist who is a SYRIZA MP now, has been producing you could see lots of good ideas that were really an alternative.

$A S:$ Is there a way for these alternatives to become a reality?

AC: These policies are now a matter of public debate in Greece. Because everyone looks at what is happening in Greece, they are debated more generally in Europe. These are quite significant developments: left wing economic policies were discussed back in the 1970s in the time of Tony Benn and François Mitterrand, because of the drive for neoliberalism they were forgotten. Now, they are not anymore. James Galbraith, the well-known left Keynesian economist, has been attacked by the Greek Right: they want to prosecute him because he was involved in Varoufakis's plans to essentially take control of the Greek financial system in the event of a confrontation with the Eurozone. That is slightly bizarre but suddenly left-wing ideas and policies are not just being discussed by only two academics in a seminar room. We see this here as 
well: last week there was a debate about Jeremy Corbyn's proposal for 'people's quantitative easing', in which a very stupid front-bencher attacked the plans in quite an economically illiterate way. The Financial Times said it is actually not a bad idea, it could work. So I think the spectrum of policy options has broadened to the left since SYRIZA's election victory, and not just in Greece and that is quite an interesting development.

AS: So far, we have seen a lot people who voted actually for an alternative, they were happy with the victory that SYRIZA and other Leftwing European parties achieved. But at the same time, we see a trend towards the neoliberal discourse. So, there seems to be a struggle for legitimising either trend within the European context.

AC: The way I see it, the neoliberals are very entrenched at the top and this is one of the striking things about the crisis that in the political élite there has been no serious consideration of alternatives to neoliberalism, but rather attempts to radicalise it. We see this here with Osborne, in particular, but also in a much more dramatic way, we see it in the Eurozone. But, it is a bit like the captain has locked himself in the centre of the ship and everywhere else the crew are mutinying. If we look at the parties of the right, some are neoliberal. That is true for UKIP here, but it is not true for the Front National or Golden Dawn, and we have also rebellion to the left. So, what we see is an élite that is more and more entrenched in neoliberalism, and it is continuing to drive our societies towards a more and more neoliberal direction, but they are attracting more and more hostility. And even here in Britain, three months ago.... it is just a depressing story UKIP taking advantage of the crisis but Jeremy Corbyn's extraordinary success in the Labour leadership elections showed that there is an audience for left-wing critiques of neoliberalism as well.

AS: Assuming that left-wing parties found their way into power, would that change the fat of Europe? Would it change people's ideas of what are good living standards, prosperity, economic growth and employment? Whatever we see now from neoliberal politics is part of the crisis of the global system, there is an increasing unemployment, there are austerity measures as you have explained, and there is a stagnating economic growth. But would left-wing politics bring about something different?

AC: That is the idea. It depends on ideas gaining material reality through popular support that is then translated into concrete policies and we have seen a big setback in Greece but I do not think it is the end of the story even in Greece, let alone elsewhere. 
AS: So politics in this sense is a learning process, whether left-wing or right-wing, it is a learning process. People should never give up on socialism or left-wing parties and that is actually a matter for the future to decide through this learning process that will take more of a tangible shape in the future.

AC: Yes.

AS: And that would apply to most of these European countries, where we see a manifestation of a struggle between right and left wing politics or ways of steering economic and social life?

AC: Yes, in principle. Though the local configuration of forces varies... in some countries the left is extremely weak. If we look at Italy for example, the Communist left has more or less disappeared. I would have said that was true for Britain a few years ago but what we have seen in Scotland and now in the Labour Party is something rather different.

AS: Let's say that there is an option of no Eurozone in the future, would that be a disaster? Would it change the future of Europe? One former British minister went to Greece and did some interviews with ordinary people, bankers, politicians and he gave them a choice between the Drachma and the Euro and all of them actually chose the Euro, even workers. People seem to be afraid of losing the future if they lose the Euro.

AC: Well, clearly that was not a representative sample because European Polls show that a significant minority would be willing to abandon the Euro. In general, I think that real progress can only be achieved through the destruction of the Eurozone. The Eurozone is a disaster. I don't see positive about it now. That does not mean I am against European cooperation or anything like that, but what we see is the most malign form of European cooperation and what has happened particularly with Greece shows that it is not amenable to reform. The Eurozone is irreparably broken and it would be better to get rid of it and start again.

AS: Starting again is to go back to the old system of economic cooperation between European countries rather than having a strict monetary system?

AC: Let me just give an example of what it is broken. The European Central Bank is designed not to be democratically accountable on the assumption that money needs to be managed by technical experts, in fact. Of course, there is nothing more political than central banking and the European bank has functioned largely to support the government forces in the European Union. This is one thing we have learned through the Eurozone crisis. Traditionally, countries were forced to change 
policies through capital flight and the fall of their currencies, but the simpler way if you do not have our own central bank, if you are part of the Eurozone, the European Central bank can just close your banks. Unless you have a plan of your own to take control of your bank, which is what Tsipras stopped Varoufakis from doing, there is very little you can do. The European Central Bank is a disaster for the people of Europe: it has to go. Now in terms of what can be put in place of the institutions of the Eurozone that would depend on the political and economic conditions that prevailed once, they had gone.

$A S$ : So, we will learn only after we get past the point where we have a Eurozone that is brining only disastrous consequences for its own countries.

AC: Yes.

$A S$ : In this sense regaining democracy, accountability, sovereignty and autonomy is actually an option that you can get once you are out of the Eurozone not within it?

$A C$ : Yes, the Eurozone is showing itself to be a thoroughly undemocratic institution.

AS: And that is an option that people should not be afraid of taking. This fact is something that these left-wing parties should start advocating and turn the attention of their people to; this attachment to Euro is something that people should be critical about?

AC: Yes, let me make it clear: I have no attachment to national currencies, it is much more convenient for there to be a single currency. I have no desire particularly to keep the Pound. So, the issue is not attachment to national currencies, but it was a good thing for Britain not to be in the Eurozone when the financial crash took place because it meant that there was a central bank that was prepared to go for quantitative easing and the currency could be devalued. The constraints Eurozone membership puts on governments are the important issue.

AS: To me, it seems that most people agree that as long as the Eurozone does not guarantee solidarity, there is no way for the Eurozone to deliver something that people want. So, a Eurozone that they have now is one without solidarity, and that is not only a social reality, it is an economic reality in itself and a political statement. And I would understand a movement in the opposite direction of the Eurozone without actually endangering or undermining the kind of social foundation of Europe. This does not mean that Europe would become more diapered with no social attachments: that there will not be a European Spirit. 
AC: I am afraid I am bit cynical about the European spirit really. When Gandhi was asked what he thought of Western civilization he said he thought it would be a good idea. Of course, we can all talk about Beethoven and things like that, but European history encompasses the Holocaust and the slave trade, and so on. I can't say I see much European solidarity but that does not mean it is not good. You can travel easily and for us, places like King's and Warwick took lots of students from the rest of Europe: all of that is very nice but solidarity in the sense of a real bond of support between different countries, I do not see it. What moves me more is the scenes that we have witnessed of refugees arriving on Greek islands where they were helped by some of the local inhabitants plus tourists. That involves a form of solidarity, which precisely transgresses Europe's borders in all sorts of ways. So, I think solidarity is exactly an important virtue that does not need to be tied to Europe in particular.

$A S$ : You mentioned at the beginning that different countries have different relationship to the Euro, could you please say a few more words about that?

AC: Yes, ok. If I am a Greek living in Greece, there is only so much money, so many Euros I can take out of my bank account every week; there is only so many Euros I can transfer abroad. If I am Belgian living in Belgium, there are not such restrictions. So, a Greek Euro means something different from what a Belgian Euro means and the same has been in Cyprus for several years although people do not notice so much.

$A S:$ And this is mainly because we have this sort of relationship to the Euro. I see the Greek economy as an entity that has a different relationship to global capital or European capital and this is why we have different relationships to the Euro...

AC: Yes, that is true for all members of the Eurozone, but Greek and Cyprus are subject to capital controls. Let me put it like this: I am going to Greece next week, as a UK citizen, in other words not living in the Eurozone, I would be able to take out (in principle at least it may not work out like this in practice) as many Euros as I like, subject to how much I have got in my bank account but my Greek cousin can only take out a very limited number of Euros every week. So, the Euro means something different for her than it does to me. So, this is a technical point but it is an indication of the fact is not a common currency.

$A S:$ So, the Euro signifies a relationship of inequality among European citizens?

AC: Yes, I mean the controls on Greece and Cyprus are in a way symbolic of the broader inequalities in the Eurozone but they are also a sign of the failure of the Eurozone. The Eurozone was meant to create a situation 
more like Europe before the First World War where you could move freely from one part of Europe to another if you had enough money: enough gold, you could spend it wherever you want. There were no limits to the movement of people and money within Europe, The Eurozone was meant to recreate that situation but we have gone back.

AS: And that is a matter of failure of whoever is in control, an institutional failure, and Germany has got a lot to do with this failure...

AC: Yes, indeed it does.

AS: Can we speak more of a European Ruling class as being part of this?

AC: I am not a great believer in transnational classes. I think it is primarily a matter of the different European ruling classes.

AS: So that means we still have, to a great extent, nationalism underway within the Eurozone?

AC: Yes, I think it is very clear that we still have nationally constituted ruling classes with cooperation that operate transitionally but they are usually tied up with one particular nation state and the Eurozone has failed to transcend that.

\section{$* * *$}

AS: How do you see the future of Europe? In light of the Eurozone crisis and more specifically in light of the Greek financial crisis?

AC: It is unoriginal, but it was a hundred years ago that Rosa Luxemburg wrote a famous pamphlet where she said: the choice facing human kid is socialism or barbarism (1915). It looks very much like that in Europe in the present time. Greece is suffering a worst depression that it suffered in the 1930s. The refugee crisis raises a whole set of other issues. For the Mediterranean to become an open coffin with thousands and thousands of people is a sign of something profoundly wrong with the way in which our world is organised at the global level. Europe is supposed to be the place where advanced values were most strongly entrenched and yet we allow this to happen. So, it seems to me we have a choice between more austerity, more neoliberalism, more closed borders, more drowned migrants; and, on the one hand, we are beginning the struggle to create a different kind of Europe where solidarity is not just something that politicians pay lip service to but is a reality.

$A S:$ Thank you very much Alex for your invaluable insights. 


\section{References}

Callinicos, A. (October 2015), 'The internationalist case against the European Union', International Socialism, 148: http://isj.org.uk/theinternationalist-case-against-the-european-union/, accessed 11 October 2015

Callinicos, A. (2014), Deciphering Capital: Marx's Capital and its Destiny, London: Bookmarks

Callinicos, A. (2012), 'Contradictions of Austerity', Cambridge Journal of Economics, 36 (1), 65-77

Callinicos, A. (October 2011), 'The Crisis of Our time', International Socialism, 132

Callinicos, A. (2010), Bonfire of Illusions: The Twin Crises of the Liberal World, London: Polity.

Callinicos, A. (July 1997), 'Europe: A Mounting Crisis', International Socialism, 2 (75)

http://pubs.socialistreviewindex.org.uk/isj75/callinic.htm, accessed 4 April 2015

European Union official website, http://europa.eu/about-eu/basicinformation/money/euro/index_en.htm, accessed 25 October 2015

Hayek, F. A. (1979), Social Justice, Socialism and Democracy: Three Australian Lectures, Turramurra, N.S.W: Centre for Independent Studies

Hayek, F. A. (1960), The Constitution of Liberty, London: Routledge and Kegan Paul

Kouvelakis, S. (2015), 'The No is not Defeated. We continue'. Partial translation of "Le non n'est pas vaincu, nous continuouns" interview in Revue Ballast, 27 July, 2015. English translation by lan Cosh, https://docs.google.com/document/d/1QX171cN63iNybHTcBI1rakq_El3 QwcfdP7wuOkkDI2Q/edit, accessed 25 June 2015

Luxemburg, R. (1915), The Junius Pamphlet: The Crisis in German Social Democracy . Translated by Dave Hollis. [Online] http://www.marxists.org/archive/luxembur/works/1915/04.htm, accessed 17 October 2015

\section{To cite this article:}

Saqer, A. (2016). A Conversation with... Alex Callinicos. Exchanges: The Warwick Research Journal, 3(2), 138-156. Retrieved from:

http://exchanges.warwick.ac.uk/index.php/exchanges/article/view/100 